\title{
TWO NEW ULTRASPECIALIZED TROGLOMORPHIC LEPTODIRINI FROM CROATIA (COLEOPTERA, LEIODIDAE, CHOLEVINAE)
}

\author{
Pier Mauro Giachino ${ }^{1}$, Achille Gasale $^{2}$ \& Branko Jalžić ${ }^{3}$ \\ ${ }^{1}$ World Biodiversity Association onlus. Private: Via della Trinità 13, I-10010 \\ San Martino Canavese (TO), Italia (p.maurogiachino@libero.it) \\ ${ }^{2}$ University of Sassari (Zoologia). Private: corso Raffaello 12, 10126 Torino (Italia) (a_casale@libero.it) \\ ${ }^{3}$ Croatian Biospeleological Society (CBSS), Rooseveltov trg 6, \\ 10000 Zagreb, Croatia (jalzicbranko@gmail.com)
}

Giachino, P.M., Casale, A. \& Jalžić, B.: Two new ultraspecialized troglomorphic Leptodirini from Croatia (Coleoptera, Leiodidae, Cholevinae). Nat. Croat., Vol. 30, No. 1, 53-72, 2021, Zagreb.

Two new ultraspecialized troglomorphic Leptodirini (Coleoptera, Leiodidae, Cholevinae) from two Croatian caves are described.

Hygrodromus (new genus) nikolinae, a new species from Mladenova cave near Orebić, is a very enigmatic taxon of "tetramerous"Leptodirini, markedly distinct for several morphological features in antennae, mouthparts, male genitalia and the peculiar sexually dimorphic apex of elytra. However, because of some characters, it could be assigned to the phyletic lineage of Hadesia and Nauticiella, which so far includes only "pentamerous"species.

Leptomeson vuicae from Dragina lipa jama cave near Čelopek in central Dalmatia, owing to its morphological features, is the south-eastern substitutive adelphotaxon of L. dombrowskii, from which it differs by its smaller size, longer elytral pubescence and the different shape of the median lobe of the aedeagus with a stouter apex.

Key words: Hygrodromus new genus, nikolinae new species, Leptomeson vuicae new species, hygropetricolous beetles

Giachino, P.M., Casale, A. \& Jalžić, B.: Dva nova ultraspecijalizirana troglomorfna leptodirina iz Hrvatske (Coleoptera, Leiodidae, Cholevinae). Nat. Croat., Vol. 30, No. 1, 53-72, 2021, Zagreb.

U radu se opisuju dva nova ultraspecijalizirana troglomorfna leptodirina (Coleoptera, Leiodidae, Cholevinae) iz dviju hrvatskih špilja.

Hygrodromus (novi rod) nikolinae je nova vrsta iz Mladenove jame kraj Orebića, vrlo enigmatična svojta 'tetramernih' leptodirina, jasno izraženih morfoloških karakteristika ticala, usnih dijelova, genitalija mužjaka, i osobitog spolnog dimorfizma apeksa pokrilja. Zbog određenih osobina mogla bi pak biti pripisana filetičkoj liniji Hadesia i Nauticiella, koja dosad uključuje samo 'pentamerne' vrste.

Leptomeson vuicae iz Dragine lipe jame kraj Čelopeka u središnjoj Dalmaciji zbog svojih morfoloških osobina predstavlja jugoistočnu sestrinsku svojtu L. dombrowskii, od koje se razlikuje manjom veličinom, dužim dlačicama na pokrilju i različitim oblikom središnjeg režnja edeagusa s debljim vrhom.

Ključne riječi: novi rod Hygrodromus, nova vrsta nikolinae, nova vrsta Leptomeson vuicae, higropetrikolni kornjaši 


\section{INTRODUCTION}

The Dinaric range in the Balkan Peninsula is a well known hotspot of subterranean biodiversity. In particular, Coleoptera Leiodidae Leptodirini (Perreau, 2000; 2015) include a high number of recently described ultraspecialized taxa (CASALE \& JALŽIĆ, 1988; CASAle et al., 2000b, 2004; ĆurČić et al., 2019; Giachino \& VAilati, 2006; Giachino et al., 2011; Mlejnek \& Moravec, 2003; Moravec \& Mlejnek, 2002; NonVEILler \& PAVIĆEvić, 1999), which have recently been investigated partly from the morphological (Perreau \& PavićEvić, 2008) and partly from the molecular point of view (Polak et al., 2016).

Within the materials collected by the members of the Second Biospeleological Expedition Pelješac 2019 (Kunarić \& Kirin, 2019), we have found an interesting leptodirine beetle living in hygropetric environment (SKET, 2004), which is described in this contribution as type-species of a new genus, together with a new species of the genus Leptomeson.

Their relationships with close taxa are illustrated and discussed.

\section{MATERIALS AND METHODS}

Morphological analysis was conducted on whole specimens and dissected male genitalia were mounted in Canada balsam and pinned under the specimens. All drawings were made using a drawing tube on a Leitz Dialux biological microscope and Wild M3 stereomicroscope. The photograph of the holotype of H. nikolinae was obtained by Gianni Allegro using a Leica DFC295 camera mounted on a Leica M205 C stereomicroscope, using the software Leica Application System V4.0. Images of habitus and male genitalia were made. Live specimens of Hygrodromus and Leptomeson were photographed in nature using an Olympus TG 4 camera.

\section{ACronyms}

The following acronyms are used for collections, type series and measurements:

HPM Cave Coleoptera Collection, Croatian Natural History Museum, Zagreb, Croatia

NMPO Biological collection of Notranjski Museum Postojna, Postojna, Slovenia

CCa A. Casale Collection, Turin, Italy

CGi P. M. Giachino Collection, San Martino Canavese (TO), Italy

HT Holotype

PT, PTT Paratype (s)

BAR Body/Antennae ratio (lengths of pronotum+elytra/antennae)

PW/PL pronotal width/pronotal length

EL/EW elytral length/elytral width 


\section{TAXONOMY}

Hygrodromus Giachino, Casale \& Jalžić gen. nov.

(Figs. 1 - 14)

Type species: Hygrodromus nikolinae n. sp.

\section{Diagnosis and description}

A genus of medium sized, tetramere protarsi in both sexes, eyeless, pubescent Leptodirini with pholeounoid body shape (Figs. 1, 18), large, subrectangular pronotum, ovate and peculiarly sexually dimorphic elytra, and antennae shorter than the body length.

Head elongate, not retractile, without occipital carina; clypeus and labrum with dense, long pubescence. Penultimate labial palpomere long and apically dilated; apical palpomere very short and stout. Antennae relatively short, inserted on the medium third of head, similar in both sexes and not reaching the elytron apex; first antennomere widened, longer than $2^{\text {nd }}$ antennomere; $11^{\text {th }}$ antennomere as long as the $10^{\text {th }}$ one.

Pronotum large and sexually dimorphic: elongate, longer than wide in the male; shorter and wider in the female, subrectangular in shape, with its maximum width just at the middle in the male, slightly bell-shaped with its maximum width just before the base in the female. Lateral sides more regularly rounded in the female; rounded anteriorly, subrectilinear basally in the male. Hind angles obtuse but evident; basal margin wider than the base of elytra. Anterior margin protruding in the middle in the male.

Pterothorax not pedunculate. Mesosternal carina absent; mesocoxal cavities contiguous.

Metatergal apparatus (Fig. 13) very reduced without posterior apophysis.

Metendosternite (Fig. 12) stout, not V-shaped, with robust furcal arm and short and stout furcal plate. Arm apophysis well developed.

Elytra elongate-ovate, moderately attenuate at apex. Apex separately rounded in the male, expanded in two large, digitiform expansions (Fig. 3) in the female. Microsculpture sparse, not forming transversal rows; disc with thin pubescence; sutural stria absent.

Legs very long and slender, with femora thickened basally. Protibiae widened just at apex, without comb but with an incomplete apical basket of spines and without outer spurs; inner spurs unifid, very small and thin. Male protarsi 4-segmented, with three dilated basal tarsomeres. Meso- and metatibiae with inner, unifid apical spur and apical basket of very short apical spines; tarsal claws long, slightly widened.

Male genital segment shoe-shaped in lateral view (Fig. 8). Aedeagus (Figs. 6, 7, 9, 10) small sized, slender, abruptly arcuate before the base; basal lamina of median lobe bent, without ventral carina; parameres shorter than the median lobe, each furnished with three setae at apex. Endophallus almost unarmed, with only a short, apical, thorny bundle.

VIII ventrite of the female (Fig. 14) without apophysis.

Ovipositor fully atrophied, genital segment membranous. Spermatheca (Fig. 11) membranous, bean-shaped, slightly sclerotized and annulated only in the basal part. 


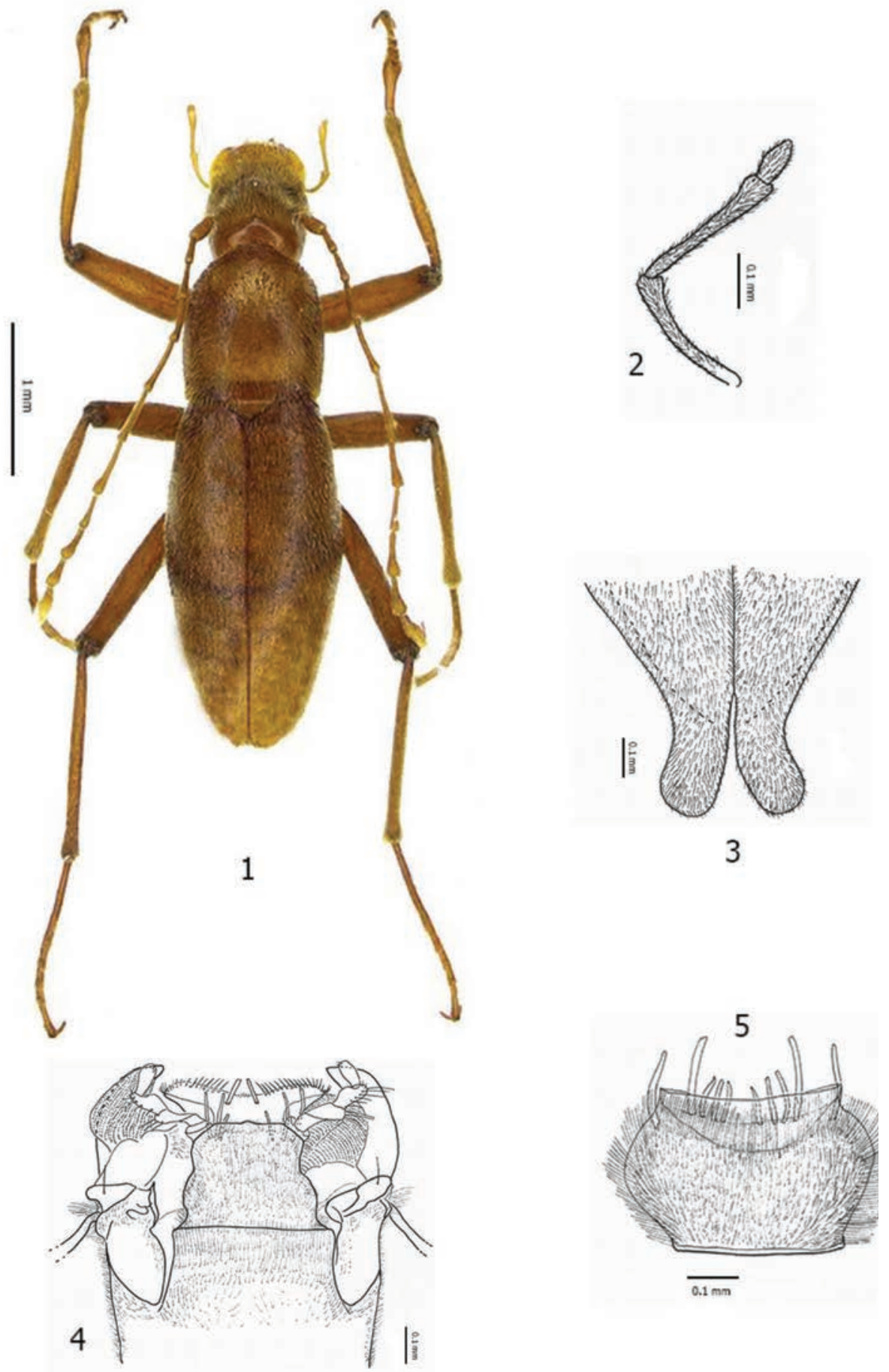

Figs. 1 - 5. Hygrodromus nikolinae n. gen. n. sp.: HT $\widehat{\partial}(1)$, PT $q$ (2 - 5). Habitus (1); maxillary palpomere, ventral view (2); elytral apex in female, dorsal view (3); head, ventral view (4); labrum, dorsal view (5). 

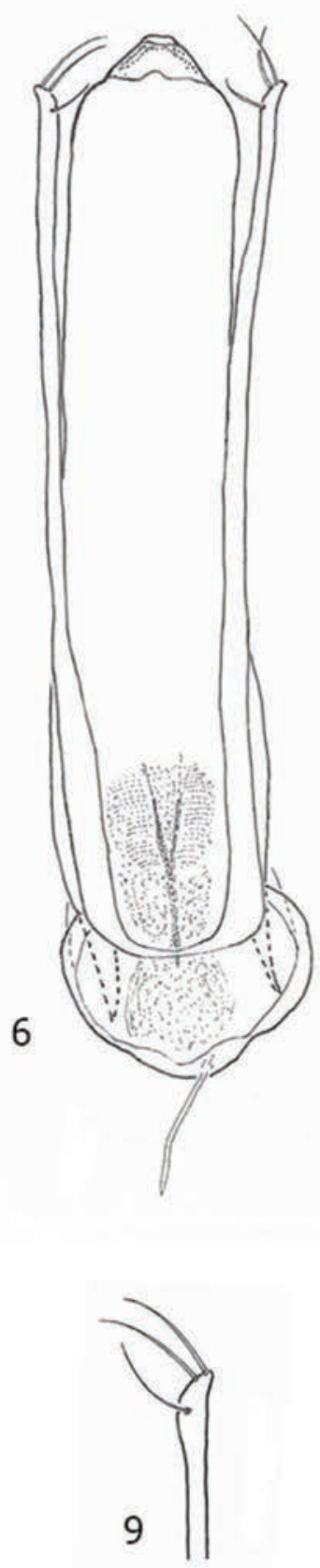
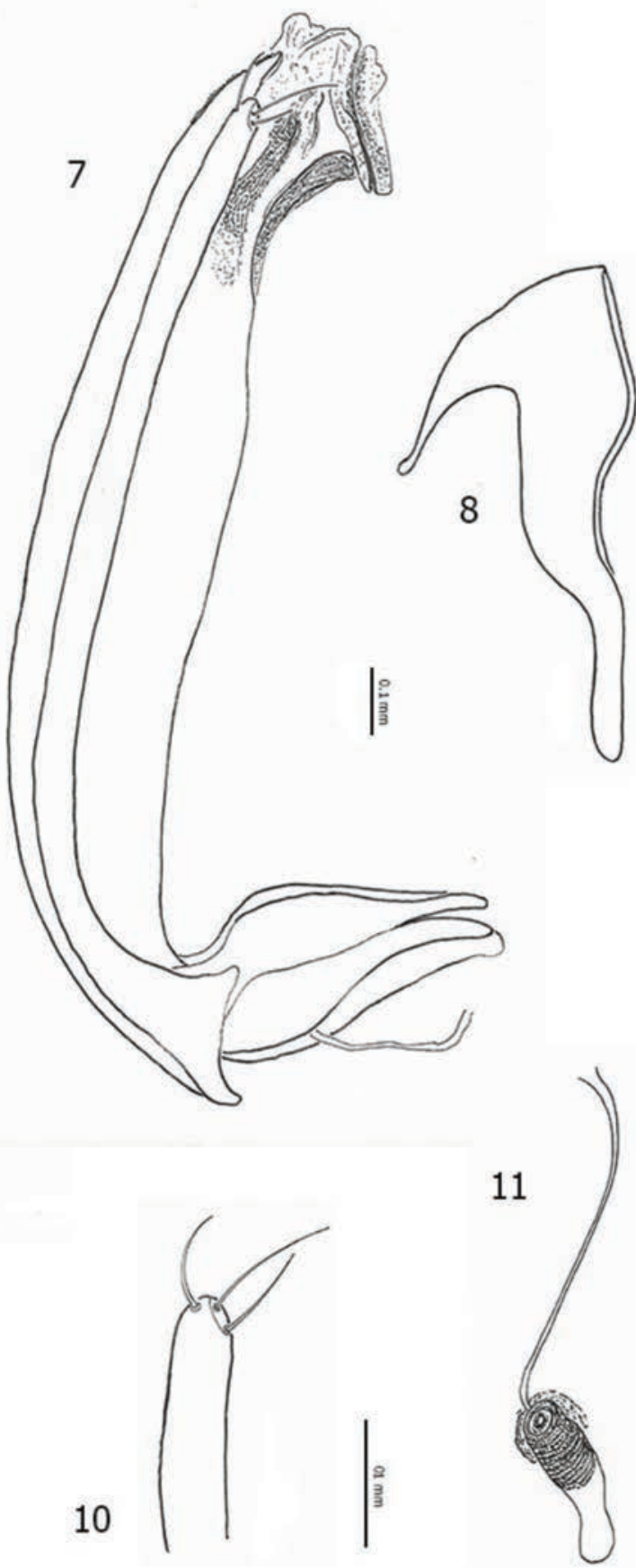

Figs. 6 - 11. Hygrodromus nikolinae n. gen. n. sp.: $\operatorname{HT} \hat{\delta}(6,9), \operatorname{PT} \hat{\delta}(7,8,10)$, PT $q$ (11). Aedeagus in dorsal view (6) and lateral view (7); apex of left paramere in dorsal view (9) and lateral view; male genital segment in lateral view (8); spermatheca (11). 

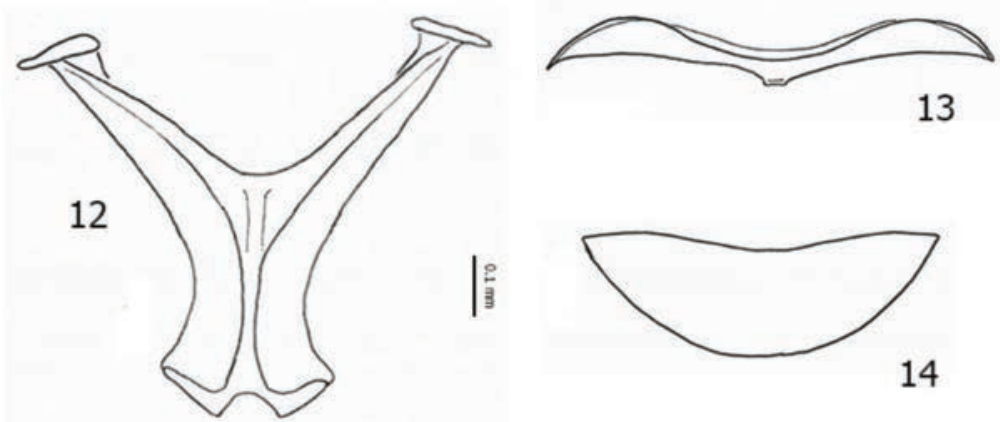

Figs. 12 - 14. Hygrodromus nikolinae n. gen. n. sp.: PT $q$. Metendosternite (12); metatergal apparatus (13); VIII ventrite in female (14).

\section{Etymology}

Hygrodromus: similar to Velebitodromus and other names of the subterranean taxa, epithet composed by "hygro", meaning wet in ancient Greek, and "drómos", to run in ancient Greek: that "runs in the wet". The name of the genus is masculine.

Hygrodromus nikolinae Giachino, Casale \& Jalžić n. sp.

(Figs. 1 - 14)

Loc. Typ.: Hrvatska, Pelješac, Orebić, Mladenova jama.

Type material: HT đ̊, Hrvatska, Pelješac, Orebić, Mladenova jama, 22.VII.2019, B. Jalžić leg. (HPM). PTT: 5 đ̄o 3 우, Hrvatska, Pelješac, Orebić, Mladenova jama, 22.VII.2019, B. Jalžić leg. (HPM, NMPO, CCa, CGi); 1 đ̃, same data, 1.IV.2019, N. Kuharić leg. (HPM); 2 $\widehat{\jmath}, 3$ 우, same data, 30.VIII.2019 B. Jalžić leg. (HPM); 1 ㅇ, same data, 27.X.2019, B. Jalžić leg. (HPM); 1 đ̊ 2 우, same data, 22.VIII.2020, B. Jalžić leg. (HPM, CCa, CGi); 1 ô, same data, 30.VIII.2020, B. Jalžić leg. (NMPO).

\section{Description}

A medium sized (body length 4.05-4.96 mm; $4.10 \mathrm{~mm}$ HT ふ̊), pholeuonoid, highly specialized leptodirine beetle. Colour dark reddish, integument opaque, pubescent Figs. 1, 18).

Head elongate, not retractile, anophthalmous, without occipital carina.

Mouth pieces (Figs. 2, 4, 5) taking long setae, i.e. adapted to filtering water and organic matter (see Jeannel, 1924; Casale \& Jalžić, 1988; Nonveiller \& Pavićević, 1999; Casale et al., 2000a, 2000b; Moravec \& Mlejnek, 2002; Mlejnek \& Moravec, 2003; Moldovan et al., 2004; Casale et al., 2004; Giachino \& Vailati, 2006). Labrum (Fig. 5) transverse, with anterior margin slightly concave and lateral margins curved, bearing, in addition to the strong and long pubescence, a set of ten modified thorns. These strong thorns, flattened and apically truncated, start ventrally and are of different lengths. Eight of them are placed along the anterior border (two long, lateral, and six in the central position). Mandibles widened and flattened in the apical half, but not twisted and not toothed on the inner edge. Maxillae short, stipe with the articles bearing tufts of long setae; lacinia reduced, the outer lobe capped by a sort of triangu- 
lar membranous and fully striated lobe. Maxillary palpi (Fig. 2) elongate, with the second palpomere thin, the third short and ovoidal. Labium (Fig. 4) fully covered by a dense, long pubescence, with anterior margin protruding in a wide and short tooth; front edge equipped, on the inner side of the mouth, with a set of six modified thorns, similar to those of the labrum. These thorns are arranged laterally in two groups of three, two long and one short. Ligula sub-trapezoidal, with anterior border markedly concave and bearing a complete range of robust setae; central area of anterior border bearing two short modified thorns (Fig. 4).

Antennae slender but not very long, more elongate in the male (BAR: 0.95 ${ }^{\lambda} ; 1.03$ q).

Length of antennomeres in $\mathrm{mm}$ :

$$
\begin{aligned}
& \text { HT ô: } 0.31 ; 0.20 ; 0.29 ; 0.32 ; 0.37 ; 0.44 ; 0.37 ; 0.27 ; 0.25 ; 0.29 ; 0.31 \\
& \text { PT } \text { ○: } 0.29 ; 0.24 ; 0.27 ; 0.34 ; 0.41 ; 0.44 ; 0.41 ; 0.34 ; 0.34 ; 0.34 ; 0.37
\end{aligned}
$$

Pronotum large in size and sexually dimorphic: elongate, longer than wide in $\widehat{\sigma}$ (PW/PL: 0.87), less elongate, more wide in + (PW/PL: 1.0). In the male subrectangular in shape, with its maximum width just at the middle; lateral sides rounded anteriorly, subrectilinear basally; anterior margin protruding in the middle. In the female slightly bell-shaped with the maximum width just before the base; lateral sides more regularly rounded; anterior margin not protruding in the middle. Hind angles obtuse but evident; basal margin wider than the base of elytra. Disc convex, covered by dense, long, decumbent pubescence, absent in the central area.

Elytra elongate-ovate (EL/EW: $2.00 \lesssim 2.02$ 우), with apex sexually dimorphic: separately rounded in the male, expanded in two large, digitiform expansions (Fig. 3) in the female. Maximum width at the middle length. Disc with microsculpture sparse, not forming transversal rows; completely covered by medium length, thin and decumbent pubescence; sutural stria absent.

Legs as in the description of the genus; male protarsi tetramerous, with three basal tarsomeres dilated; the basal protarsomere, markedly dilated, is wider than the apex of protibia. First tarsomere of the pro-, meso- and metatibiae as long as the sum of the following. Femora widened at base, tibiae straight.

Aedeagus (Figs. 6, 7, 9, 10) small sized, slender. Median lobe, in lateral view, abruptly bent at the base, with basal lamina bent, without ventral carina. In dorsal view elongate, with subparallel sides almost to the apex, which is subtriangular and slightly truncate. Parameres shorter than the median lobe, each bearing three setae: two apical and another one subapical, placed on the inner side. Endophallus almost unarmed, with only a short, apical, thorny bundle.

Female genitalia as in the description of the genus.

\section{Etymology}

The new species was named in honor of Nikolina Kuharić, member of the Croatian Biospeleological Society who discovered the first specimen. 


\section{Distribution and ecology}

\section{Topographic location and habitat}

Mladenova cave is situated in the Pelješac peninsula (Fig. 15), west of the peak Sv. Ilija (at $961 \mathrm{~m}$ asl). It was formed by water draining along numerous tectonic fissures in the Lower Cretaceous rocks in the northern wing of the anticline extending from east to west. Geologists describe these rocks as a unique complex of limestone and breccia sediments (K1, 2-4) (MARINČIĆ et al., 1977; MAGAŠ et al., 1979) .

It belongs to the type of vertical cave with numerous verticals following the inclination of the fault surface. Verticals and larger chambers are connected to each other via narrow passages. The middle part is rich in limestone formations, most notably flowstones (Fig. 16). Depending on precipitation, the draining water sinks into the cave and forms a small waterflow at a depth of $100 \mathrm{~m}$. During every investigation, a permanent waterflow was identified at the depth of $190 \mathrm{~m}$. In this part the cave hygropetric habitat is characterized by the presence of a layer of moonmilk. These are the places where the hygropetricolous beetles were found (Fig. 17).

Other species of beetles also inhabit the cave: Neotrechus dalmatinus, Laemostenus cavicola, Adriaphaenops sp. and Troglamaurops cf. leptoderinus.

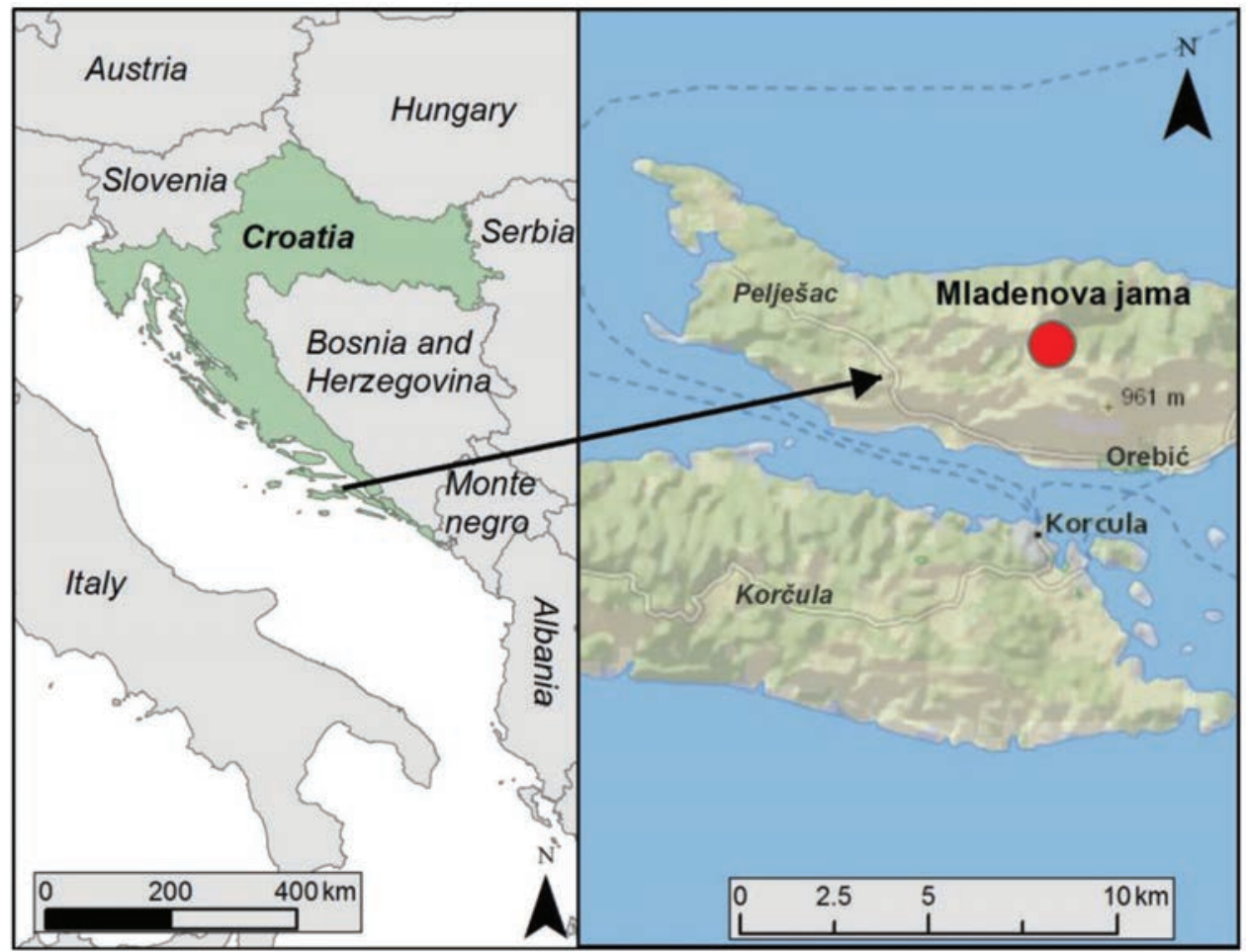

Fig. 15. The map with position of Mladenova jama 


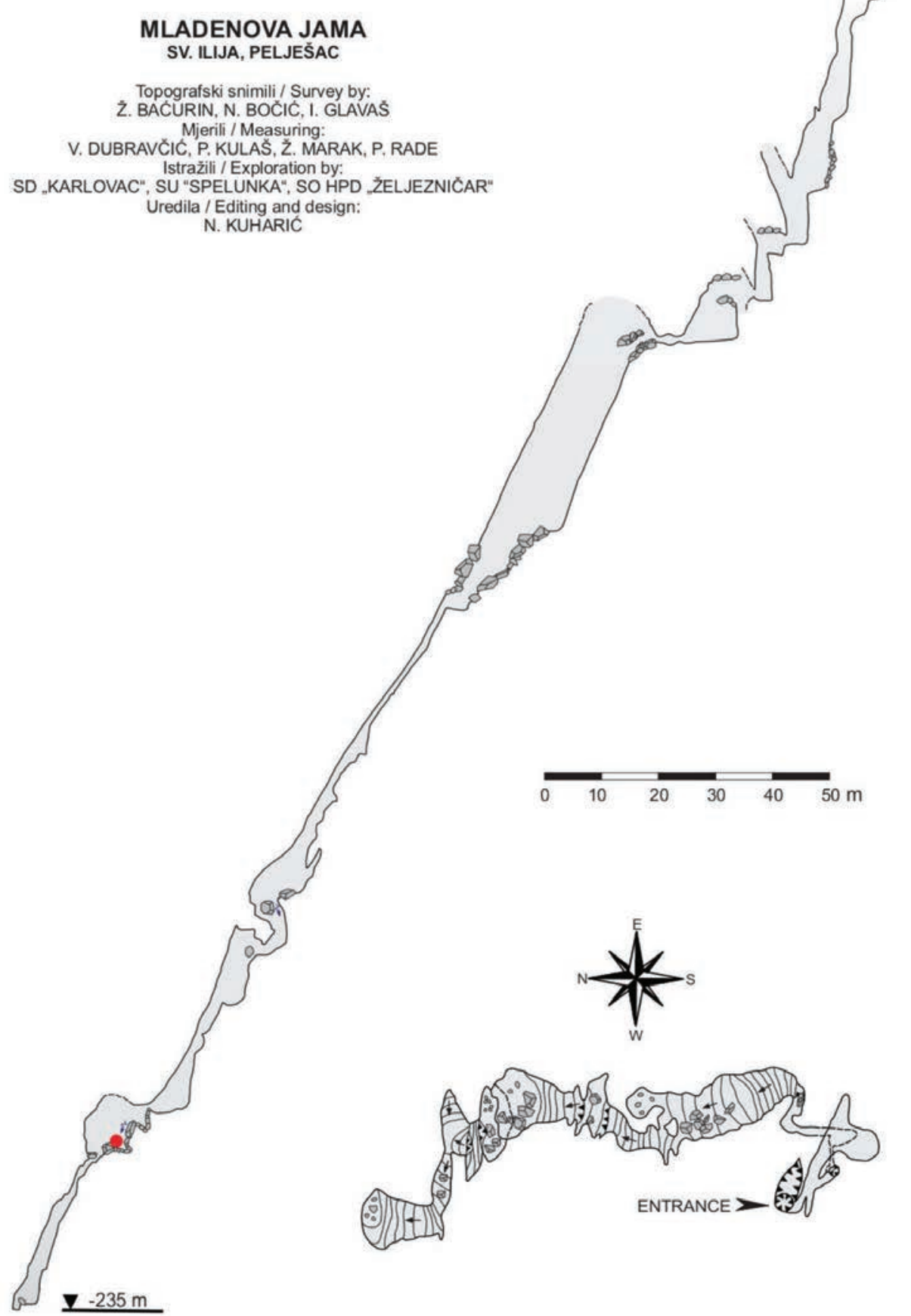

Fig. 16. Topographic plan of Mladenova jama, with marked place of finds. 

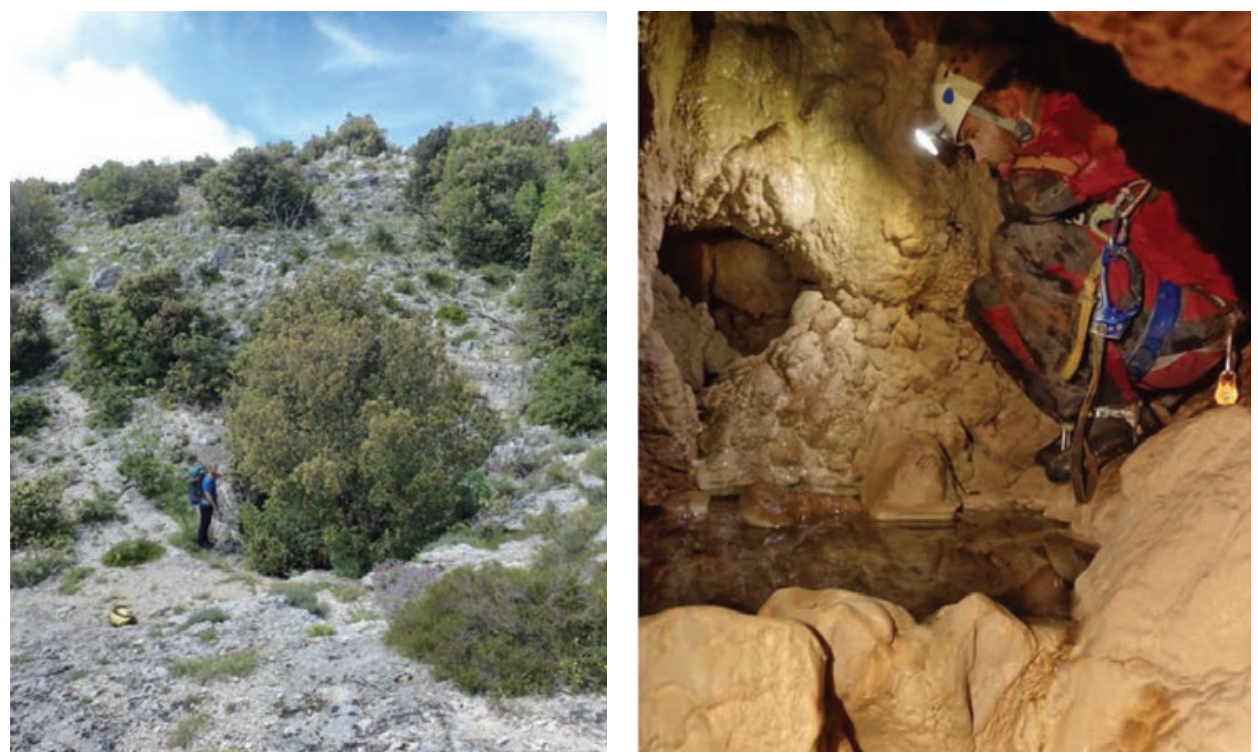

Fig. 17. The entrance and habitat in Mladenova jama (photo B. Jalžić).

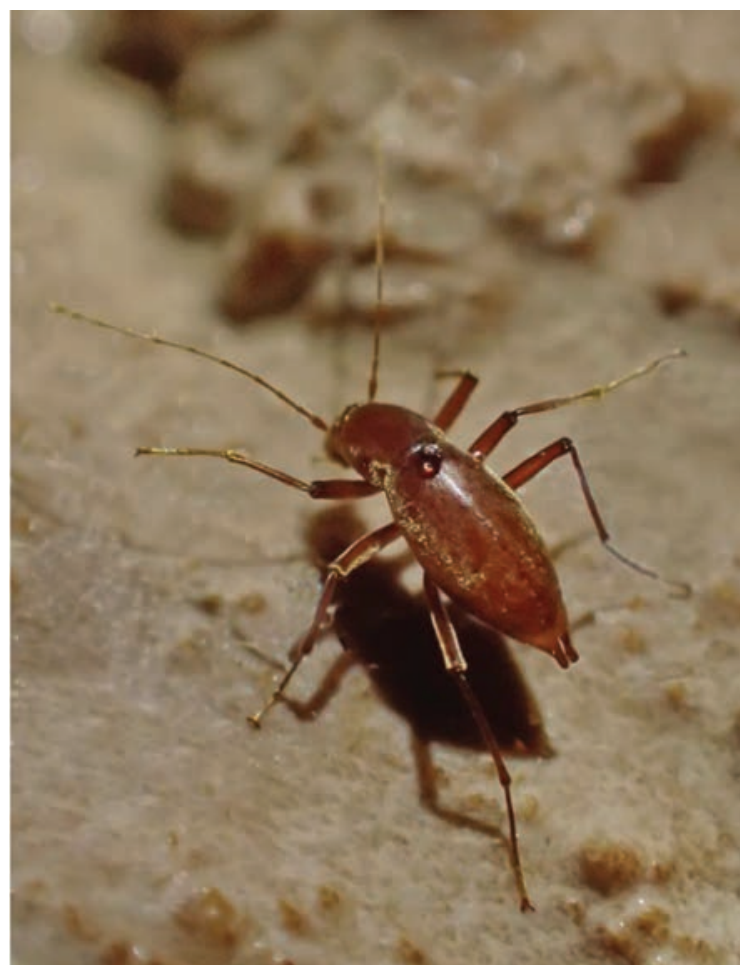

Fig. 18. Hygrodromus nikolinae, female in natural habitat (photo B. Jalžić). 


\section{Taxonomy}

Subsequently to the excellent monograph by JEAnnel (1924), the taxonomy and phylogeny of Cholevinae Leptodirini (treated by Jeannel as "Bathysciinae") were discussed in many contributions (see, amongst others: FrESNEDA et al., 2011; GIACHINO et al., 1998; Guéorguiev V.B., 1990; Perreau, 2000, 2015; Perreau \& Pavićević, 2008). Furthermore, thanks to recent speleological explorations in deep and large caves, mostly in the Balkan peninsula, discoveries of ultraspecialized hygropetricolous Leptodirini highly adapted to the peculiar environment described by SKET (2004) ("amphibiontic species"in the sense of Moravec \& Mlejnek, 2002, or species with "hadesian behavior" in the sense of Nonveiller \& PAvićEvić, 1999) have dramatically increased.

Many described taxa exhibit important derived characters in their external morphology, and share with other troglomorphic genera many features of similar appearance, which however seem to be mere homoplastic characters resulting from convergent evolution.

In this context, Hygrodromus (new genus) nikolinae Giachino, Casale \& Jalžić new species is a very enigmatic taxon from the taxonomic and phylogenetic points of view.

Despite its four-segmented male protarsi, several other morphological features seem to exclude its attribution to the tetramere lineages of PERrEaU (2000), including Bathysciotina, Spelaeobatina and Bathysciina. Regarding some characters, such as the sexually dimorphic apical margins of elytra, it is somewhat similar to Radziella Casale \& Jalžić, 1988, from which it is distinct, however, by the completely different maxillary palpi and female spermatheca. This feature, even if with different degrees of development, appears in different unrelated taxa, of different subtribes and it is clearly a homoplasy. This is also true for Tartariella Nonveiller \& Pavićević, 1999, another hygropetricolous tetramere genus close to Leonhardella Reitter, 1903 (see NoNVEILler \& PAVIĆEvić, 1999). All other tetramere representatives of the genus Spelaeobates in the Dinaric area are completely different in both external and genital features.

On the contrary, for several of its morphological features, the new taxon in our opinion could be related to the lineage of Hadesia Müller, 1911 and Nauticiella Moravec \& Mlejnek, 2002, which include so far only pentamere genera (i.e. Leptodirina, Anthroherponina, Pholeuina of Perreau, 2000). In fact, Hygrodromus nikolinae shares with these two genera several apomorphic characters in the antennal features (with second antennomere much shorter than the first), in the shape of maxillary palpi, the structure of tibiae and the shape of both aedeagus and spermatheca. Furthermore, there is also a perceptible diversification of the sexually dimorphic elytral apex in Hadesia (see Polak et al., 2016) and Nauticiella (Moravec \& Mlejnek, 2002; Mlejnek \& Moravec, 2003), even if this feature is present in different subtribes of Leptodirini.

Leptomeson vuicae Giachino, Casale \& Jalžić, n. sp. (Figs. 19 - 24, 29)

Loc. Typ.: Hrvatska, Metković, Borovci, Čelopek, Dragina lipa jama.

Type series: HT つ̊, Hrvatska, Metković, Borovci, Čelopek, Dragina lipa jama, 5. XI.2019, leg. B. Jalžić (HPM). PTT: 5 q , Hrvatska, Metković, Borovci, Čelopek, Dra-

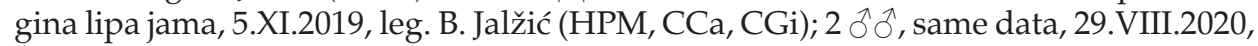
leg. B. Jalžić (CCa, CGi); 3 ỗ ô, 18 of ㅇ, same data, 4.IX.2020, leg. B. Jalžić (HPM, CCa, CGi); 2 ふึત, same data, 21.VIII.2020, leg. P. Visković (HPM). 


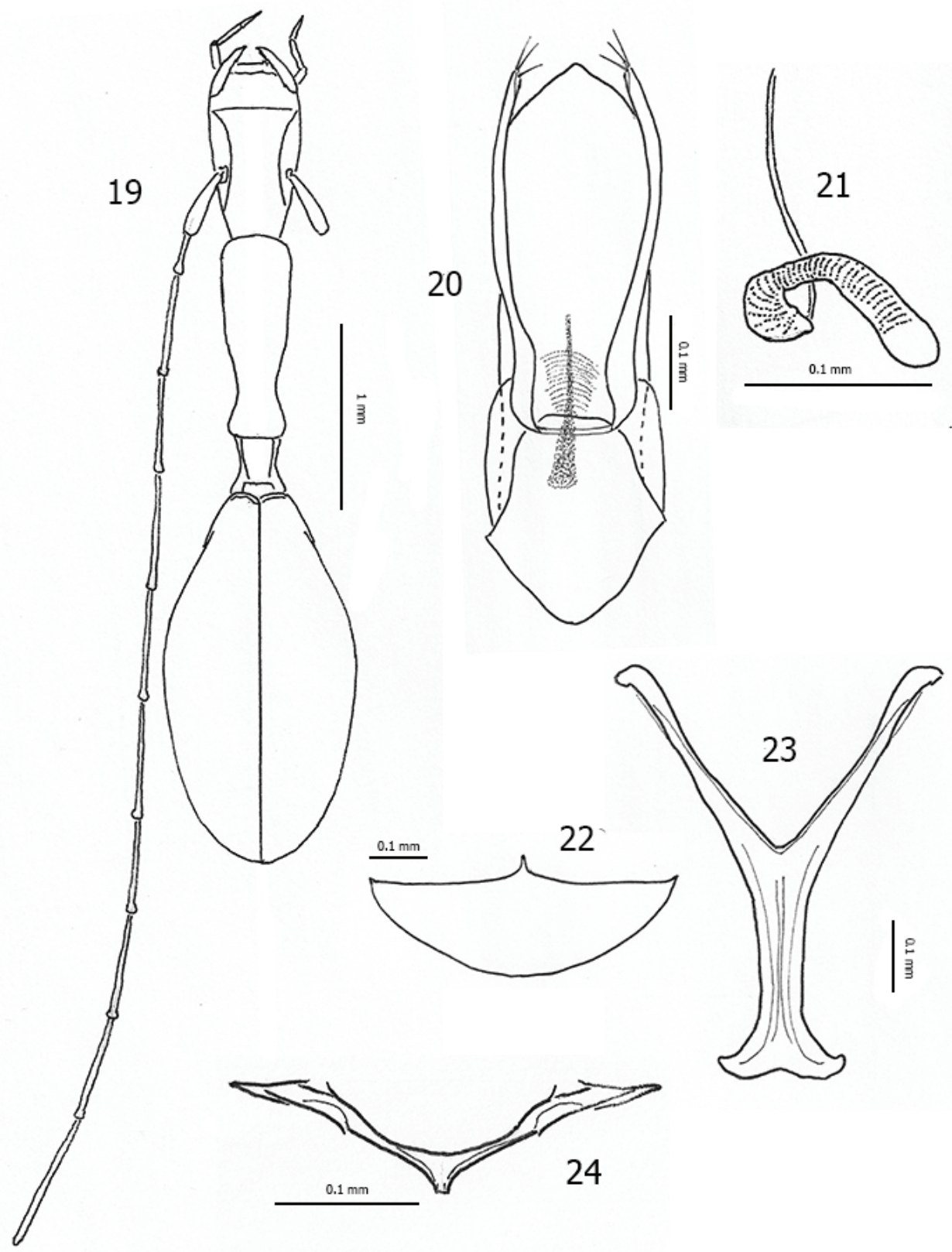

Figs. 19 - 24. Leptomeson vuicae n. sp.: $\operatorname{HT} \precsim(19,20)$, PT $q(21-24)$. Habitus (19); aedeagus in dorsal view (20); spermatheca (21); VIII ventrite in female (22); metendosternite (23); metatergal apparatus (24). 


\section{Diagnosis}

A small-sized Leptomeson species (body length 4.30-4.65 mm), which resembles $L$. dombrowskii (Apfelbeck, 1907), L. raguzi Giachino, Bregovic \& Jalžić, 2011 and L. biokovensis Giachino, Bregovic \& Jalžić, 2011 based on small body size and the shape of the aedeagus. It differs from $L$. dombrowskii s.l. by the longer elytral pubescence and by the shape of the median lobe of aedeagus with stouter apex. It differs from L. biokovensis by the shorter elytral pubescence and by the shape of the median lobe of aedeagus without pointed apex. It differs also from L. raguzi by the shorter antennae and by the different shape of pronotum, not restricted in the anterior third.

\section{Description}

Total body length with extended head 4.30-4.65 mm (4.37 mm HT §). Colour testaceous, with legs, palpi, and antennae slightly lighter. Body (Figs. 19, 28) leptodiroid, very elongate, with physogastric and convex elytra, and the pronotum narrow and very elongate. Integuments shiny, with the microsculpture much weaker on head, evident on pronotum; evident and not aligned in transversal strioles on the elytral disc. Integuments covered with a sparse pubescence, upright and long on head; very sparse and very short, on the basal part of pronotum; sparse, golden, long and upright on the elytra.

Head, very elongate, anophthalmous, without occipital carina, remarkably widened in front. Medium specialized mouthparts, with the upper part of the mandibles clearly concave; maxillary palpi elongate, having the penultimate palpomere subconical, widened at the distal end, and the last palpomere conical and very elongate. Antennae very long, (BAR $0.56 \hat{\sigma}, 0.55$ o ), frail, with the $2^{\text {nd }}$ antennomere shorter than the first one and the $11^{\text {th }}$ only slightly longer than the $10^{\text {th }}$ one in $\delta^{1}$ and $q ; 8^{\text {th }}$ visibly shorter in $\delta$ than in $\rightarrow$.

Length of antennomeres in $\mathrm{mm}$ :

ก $0.37 ; 0.20 ; 0.51 ; 0.51 ; 0.62 ; 0.58 ; 0.62 ; 0.51 ; 0.55 ; 0.58 ; 0.75$

ㅇ $0.31 ; 0.24 ; 0.62 ; 0.55 ; 0.68 ; 0.58 ; 0.58 ; 0.62 ; 1.03 ; 0.51 ; 0.68$

Pronotum cordiform, very elongate (PW/PL: $0.35 \hat{\sigma}, 0.35$ 9 ) and bottlenecked before the base at about one third of its length, with the maximum width just before the anterior edge and with the base slightly narrower than it. Sides strongly sinuate on the basal part, subrectilinear in the distal half and finely rebordered in the basal half; basal angles obtuse and blunted; base subrectilinear and not rebordered. Pronotal disc completely glabrous, with evident microsculpture in the basal half.

Mesothoracic peduncle very elongated, about as long as the basal part of the pronotum, flat and slightly concave dorsally, bearing a very strong microsculpture with an isodiametric polygonal mesh.

Mesosternum without a true mesosternal carina; the mesosternum is ventrally slightly angled anteriorly. Prosternum carinate, bearing a long and sharp sagittal carina behind the coxae.

Metatergal apparatus (Fig. 24) very reduced, with frail lateral arms and posterior apophysis reduced to a stump.

Metendosternite (Fig. 23) V-shaped, with furcal arms thin and furcal trunk long and not particularly stout. 
Elytra very elongate (EL/EW: 1.90 $\hat{0}, 1.70$ o ), slightly pyriform, more physogastric in the $q$, with the largest width just before the mid-section, separately and briefly rounded apically; disc very convex, with the pubescence extremely sparse (slightly denser along the elytral suture), long and upright. Sutural stria absent.

Legs very long and frail, with femora enlarged and swollen in the basal part, progressively tapering distally. Tibiae straight, not enlarged distally; claws long and slightly enlarged. Anterior tarsi pentamerous and not dilated in the $\widehat{\sigma}$.

Aedeagus (Fig 20), robust, short and poorly arcuate; median lobe, in dorsal view, stocky, with the apex subtriangular and not protruding beakwise. Basal blade of the median lobe stocky, short and enlarged. Parameres frail, about as long as the median lobe, in dorsal view, regularly curved, tapering, from the middle to the apex and bearing three apical setae. Internal sac bearing a short sclerified stylet-shaped flagellum in the basal part.

VIII ventrite of the female (Fig. 22) with small and pointed apophysis.

Spermatheca (Fig. 21) small, anulated and poorly sclerified, vaguely G-shaped.

\section{Etymology}

This new species is named in honor of Markica Vuica, President of the Baštinik Association in Metković.

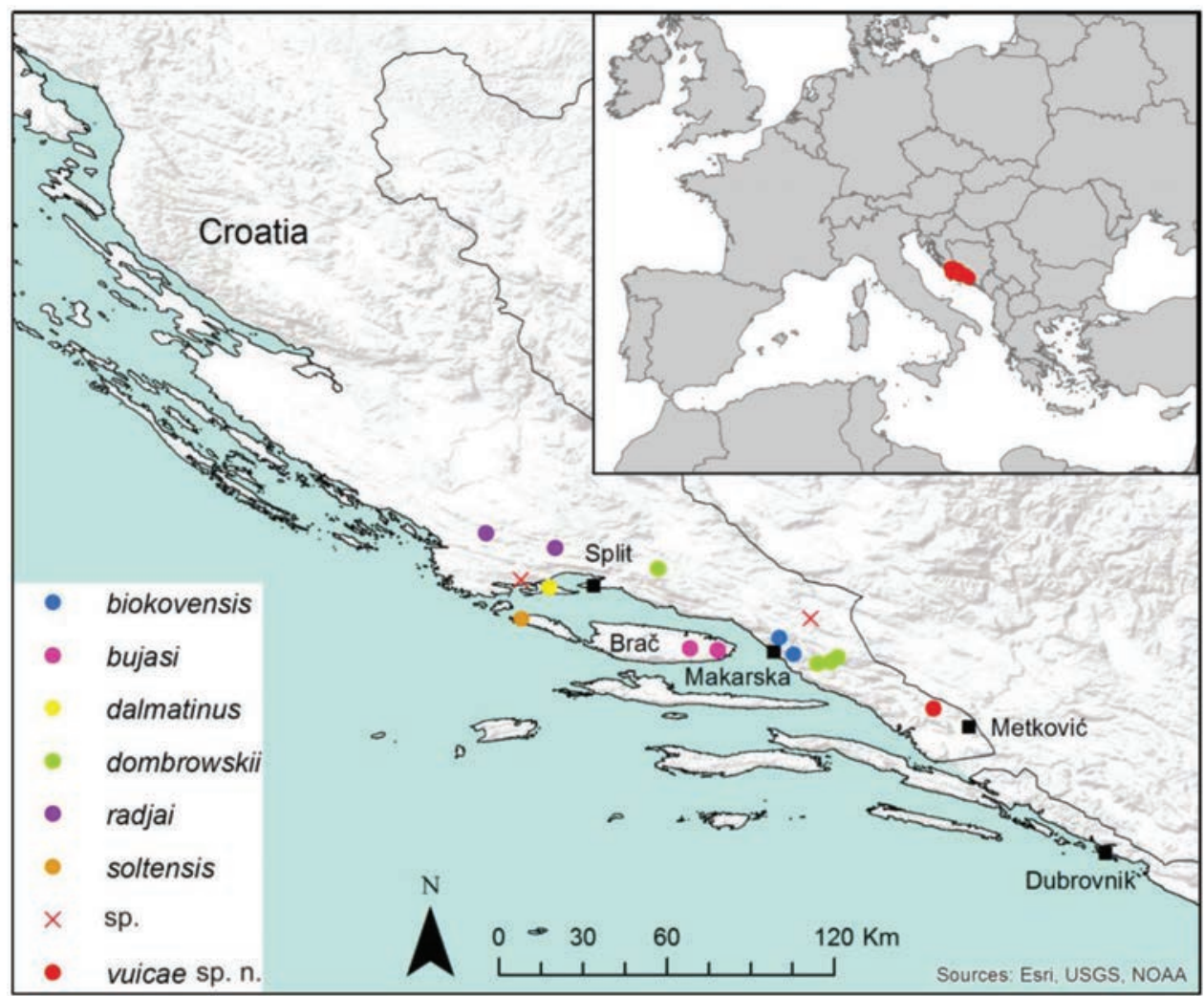

Fig. 25. Distribution map of the genus Leptomeson in Croatia. 


\section{Distribution and ecology}

It is very important to upgrade the distribution map provided by GIACHINO et al. (2011), with the inclusion of Leptomeson soltensis and also the new species (Fig. 25).

\section{Topographic location and habitat}

Dragina lipa jama is situated in central Dalmatia, northwest of the town of Metković, not far from the locality of Borovci, near the village of Čelopek.

The cave is situated rudist limestone sedimented during the Upper Cretaceous at the cross section of two fault zones. The first fault zone of Dinaric spreading of a regional character represents an example of thrust tectonics by which the Upper Cretaceous sediments are found on top of the Paleogene sediments MARINčić et al., 1977; MAGAŠ et al., 1979). The second fault zone spreads from north to south, has a local character and cuts through the first zone.

The entrance is small and was closed by a stone boulder before our arrival. The cave belongs to the type of vertical caves with several smaller verticals and a wide, inclined cave channel. Numerous speleothems are found, throughout the cave (Fig. 27).

Individuals of L. vuici were found below a depth of $70 \mathrm{~m}$ (Fig. 26).

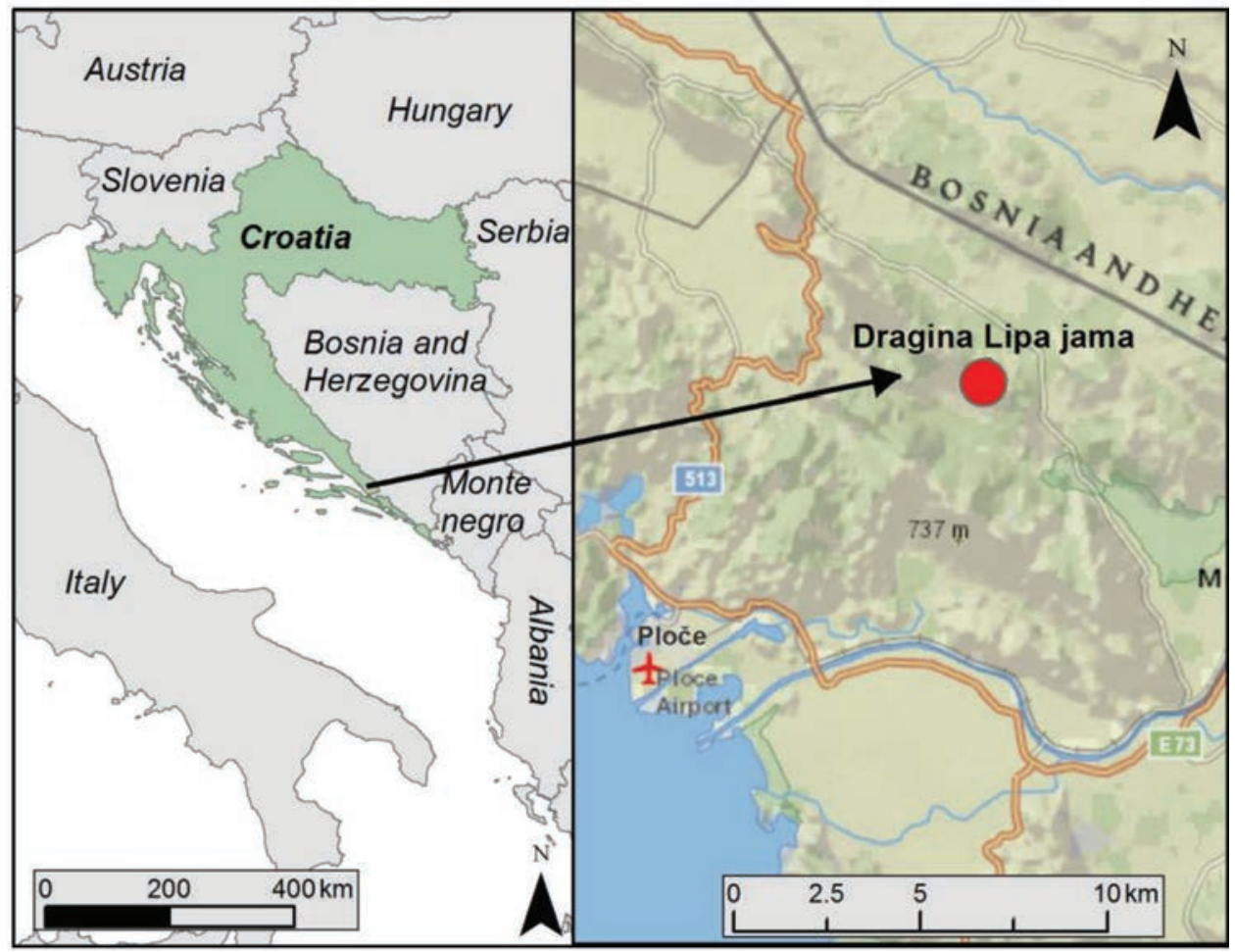

Figs. 26. The map with position of Dragina lipa jama. 


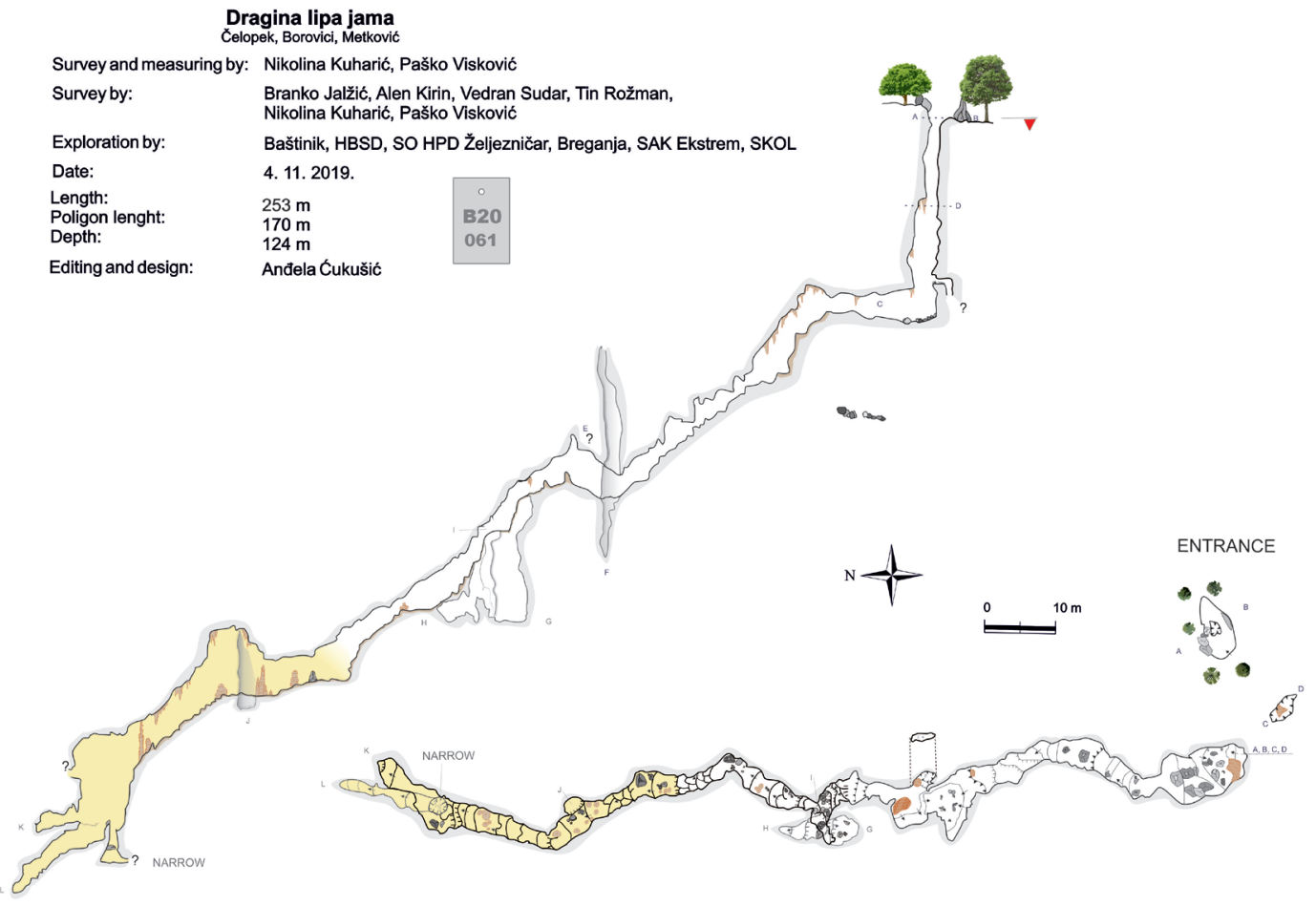

Fig. 27. Topographic plan of Dragina lipa jama, with marked area of finds.
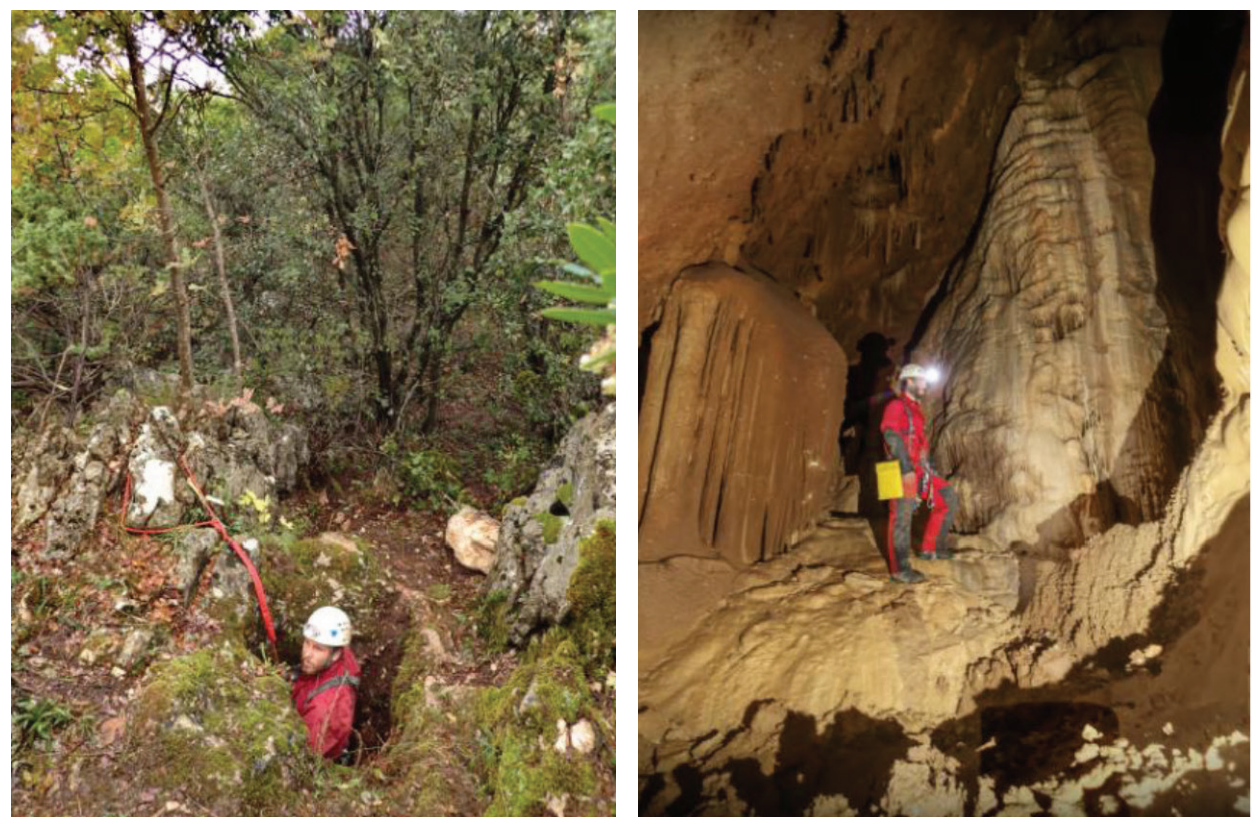

Fig. 28. The entrance and habitat in Dragina lipa jama (photo B. Jalžić). 


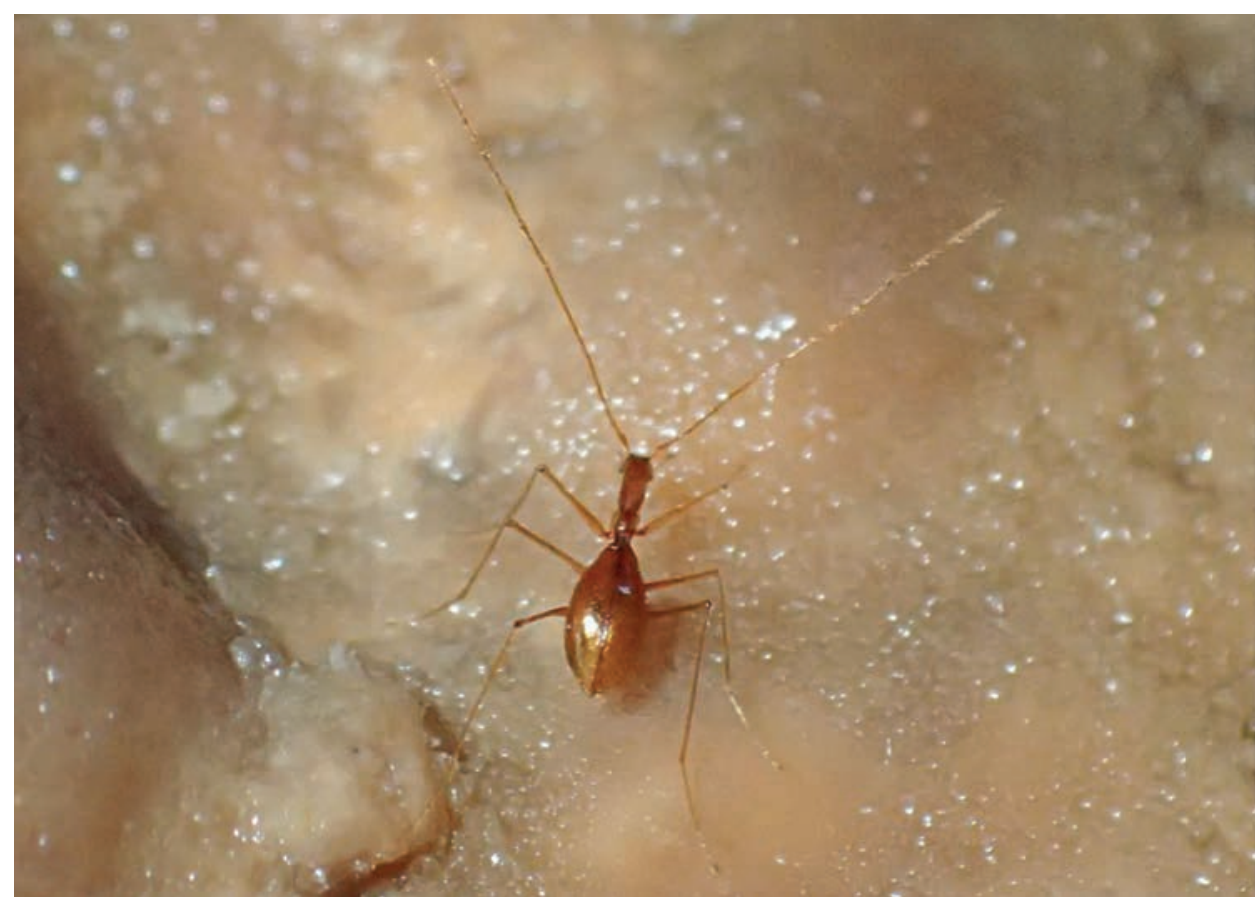

Fig. 29. Leptomeson vuicae in natural habitat (photo B. Jalžić).

Other cave beetles also inhabit the cave, such as Neotrechus dalmatinus and Speonesiotes narentinus.

The temperature measured on $23^{\text {rd }}$ November 2019 at the bottom of the cave was $14^{\circ} \mathrm{C}$.

\section{Taxonomy}

Owing to its morphological features, this new species seems to be the south-eastern adelphotaxon of L. dombrowskii, from which it differs by the smaller size, the longer elytral pubescence and the different shape of the median lobe of the aedeagus with a stouter apex.

The following identification key, also following the contribution of Ćurčić et al. (2019), modifies and updates the key provided by Giachino et al. (2011).

\section{Key to the species of genus Leptomeson Jeannel, 1924:}

1. Mesothoracic peduncle not narrowed in the middle, wider back. . . . . . . . . 2

- . Mesothoracic peduncle narrowed in the middle, very elongate, always longer than

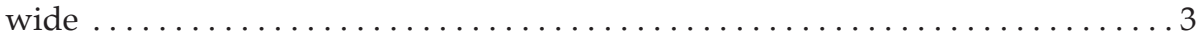

2. Elytra with the largest width at the mid-section, attenuated posteriorly. Larger in size $(\mathrm{mm} 6.4-7.0) \ldots \ldots \ldots \ldots \ldots \ldots \ldots \ldots \ldots \ldots \ldots \ldots \ldots \ldots \ldots$ svircevi svircevi Müller

- . Elytra with the largest width after the mid-section, swollen posteriorly. Smaller in size $(\mathrm{mm} 6.0-6.3 \ldots \ldots \ldots \ldots \ldots \ldots \ldots \ldots \ldots \ldots \ldots \ldots \ldots \ldots \ldots \ldots$ svircevi knirschi Guéorguiev 
3. Pubescence of the elytral disk very long and dense; larger in size species ( $\mathrm{mm} 6.2$ $-7.0)$. . loreki Zoufal

- . Pubescence of the elytral disk short or long, but always sparse, or sparse on the disk and more dense at least towards the base, or elytral disk almost completely

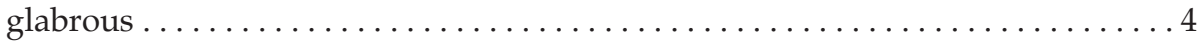

4. Pubescence of the elytral disk short and sparse. Larger size $(\mathrm{mm} 5.7-6.2) \ldots \ldots$

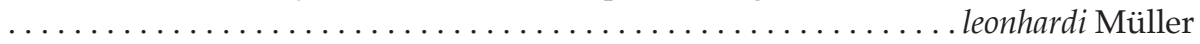

- . Pubescence of the elytral disk short or long. Smaller size (mm $4.0-5.13) \ldots . .55$

5. Strong evident microsculpture of the pronotum. Pubescence of the elytral disk

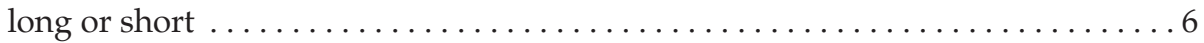

- . Less evident microsculpture of the pronotum. Pubescence of the . . . . . . . . .

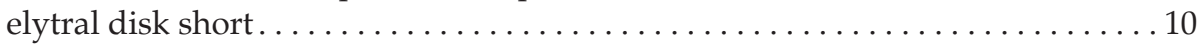

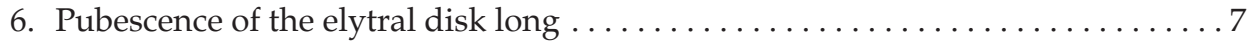

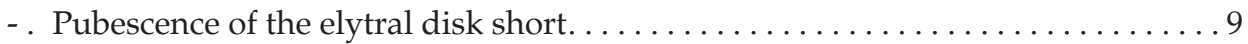

7. Pubescence of elytra very long and upright. Larger species (length $>\mathrm{mm} 5.0$ )... biokovensis Giachino, Bregović \& Jalžić

- . Pubescence of elytra long and upright. Smaller species (length $<$ mm 5.0) $\ldots .8$

8. Antennae less elongate (BAR: 0.64$) \ldots \ldots \ldots$ raguzi Giachino, Bregović \& Jalžić

- . Antennae more elongate (BAR: $0.55-056) \ldots \ldots \ldots \ldots \ldots \ldots \ldots$ vuicae $\mathbf{n} . \mathbf{s p}$.

9. Pubescence of elytra strong at the base, completely deleted at apex ........... dombrowskii dombrowskii Apfelbeck

- . Pubescence of elytra sparse, a little bit denser towards the base . . . . . . . . . . . $\ldots \ldots \ldots \ldots \ldots \ldots \ldots \ldots \ldots \ldots \ldots \ldots \ldots \ldots \ldots \ldots \ldots \ldots \ldots$ dombrowski pubipennis Müller

10. Aedeagus with parameres bearing three apical setae and one internal and subapical (mm 4.68-5.13) . . . . . . . . . . . . radjai Giachino, Bregović \& Jalžić

- . Aedeagus with parameres bearing three apical setae only $\ldots \ldots \ldots \ldots \ldots \ldots 11$

11. Apex of the median lobe of the aedeagus, in dorsal view, subtriangular; parameres not twisted at apex (mm 4.97-5.06) . . . . . . . . bujasi Giachino, Bregović \& Jalžić

- . Apex of the median lobe of the aedeagus, in dorsal view, subtriangular or rounded and strongly protruding beak shape; parameres twisted at apex. . . . . . . 12

12. Apex of the median lobe of the aedeagus, in dorsal view, rounded and strongly protruding beak shape; parameres as long as the median lobe. (mm 4.26-5.10) ... dalmatinus Giachino, Bregović \& Jalžić

- . Apex of the median lobe of the aedeagus, in dorsal view, subtriangular; parameres shorter than the median lobe of aedeagus ( $\mathrm{mm} 4.65-5.05)$

soltensis Ćurčić \& Rađa 


\section{ACKNOWLEDGEMENTS}

We owe great thanks to the participants of the Second Biospeleological Expedition Pelješac 2019, the speleologist Paško Visković from Tučepi and geologists Vedran Sudar from Zagreb, Mladen Bikić and Mario Tomašić from Orebić. We also thank the speleologists and members of the Baštinik Association who conducted speleological and biospeleological research: Nikolina Kuharić, Alen Kirin and Tin Rožman. We also thank the president of Baštinik, Markica Vuica, for help with organization and field work, and Drago, Jura, and Luka Vekić for opening the entrance of Dragina lipa cave and providing help in the field.

A particular acknowledgement is also due to our friend Gianni Allegro, who took the habitus photo of the holotype of Hygrodromus nikolinae, and for financial support: Jama Grotta - Baredine, Croatian Waters and Dubrovnik-Neretva County, the Kula Norinska Municipality, City of Metković and the Ministry of Environmental Protection and Energy.

Biospeleological research was conducted with a permit from the Ministry of Environmental Protection and Energy: KLASA: UP/I-612-07/19-48/25, URBROJ: 517-051-1-19-4, 27.2.2019.

Received March 10, 2021

\section{REFERENCES:}

Casale A. \& Jalžıć, B., 1988: Radziella (new genus) styx n. sp., a new exceptional troglobitic Bathysciinae (Coleoptera, Catopidae) from the Dinaric Region, Jugoslavia. Bollettino del Museo regionale di Scienze naturali di Torino, 6(2), 349-358.

Casale, A., Carcupino, M., Manca, I. \& Giachino, P.M., 2000: Ultrastructure of filtering mouth parts in highly specialized troglobitic Leptodirinae (Coleoptera, Cholevidae). XXI International Congress of Entomology, Foz do Iguassu, Brazil, 2000, Abstract Book, p. 936.

Casale, A., Giachino, P.M. \& Jalžıć, B., 2000b: Croatodirus (nov. gen.) bozicevici n. sp., an enigmatic new leptodirine beetle from Croatia (Coleoptera, Cholevidae). Natura Croatica, 9(2), 83-92.

Casale, A., Giachino, P.M. \& Jalžić, B., 2004: Three new species and one new genus of ultraspecialized cave dwelling Leptodirinae from Croatia (Coleoptera, Cholevidae). Natura Croatica, 13(4), 301317.

Ćurčić, S., Vesović, N., Lazović, V., Pantelić, D. \& RaĐA, T., 2019: A new troglobitic species of the genus Leptomeson Jeannel, 1924 (Coleoptera: Leiodidae: Cholevinae: Leptodirini) from the Island of Šolta (middle Dalmatia, Croatia). Zootaxa, 4711(1), 193-200.

Fresneda, J., Grebennikov, V.V. \& Ribera, I., 2011: The phylogenetic and geographic limits of Leptodirini (Insecta: Coleoptera: Leiodidae: Cholevinae), with a description of Sciaphyes shestakovi sp.n. from the Russian Far East. Arthropod Systematics \& Phylogeny, 69(2), 99-123.

Giachino, P.M., Bregović, P. \& Jalžıć, B., 2011: Five new species of the genus Leptomeson Jeannel, 1924 from Croatia and Bosnia and Herzegovina (Coleoptera, Cholevidae, Leptodirinae). Natura Croatica, 20(2), 355-374.

Giachino, P.M., Vailati, D. \& Casale A., 1998: Major questions in the phylogeny and biogeography of Cholevidae (Coleoptera), with emphasis on the subfamily Leptodirinae. Pp. 179-209 in: Giachino, P.M. \& Peck, S.B. (eds), Phylogeny and Evolution of Subterranean and Endogean Cholevidae (= Leiodidae Cholevinae). Proceedings of a Symposium (30 August, 1996, Florence, Italy) at XX International Congress of Entomology. Atti del Museo Regionale di Scienze Naturali, Torino.

Giachino, P.M. \& Vailati, D., 2006: Kircheria beroni, a new genus and new species of subterranean hygropetricolous Leptodirinae from Albania (Coleoptera, Cholevidae). Subterranean Biology 4, 103-116. 
Guéorguiev, V.B., 1990: Recherches sur les Bathysciinae (Coleoptera: Catopidae) de Yougoslavie. I. Antroherponini. Acta Entomologica Musei Nationalis Pragae 43, 237-273.

Jeannel, R., 1924: Monographie des Bathysciinae. Archives de Zoologie Expérimentale et Générale 63(1), $434 \mathrm{pp}$.

Kuharić, N. \& Kirin, A., 2019: Druga biospeleološka ekspedicija - Pelješac 2019. Subterranea Croatica 18(28), 19-33.

Marinčić, S., MAGaŠ, N. \& BenČEk Đ., 1977: Osnovna geološka karta 1:100000, list Ploče K 33-35. Beograd: Savezni geološki zavod, Beograd.

Magaš, N., Marinčić, S. \& Benček Đ., 1979: Osnovna geološka karta 1:100000, Tumač za list Ploče, K 33-35. Beograd: Savezni geološki zavod, Beograd.

Mlejnek, R. \& Moravec, J., 2003: Description of the female of Nauticiella stygivaga (Coleoptera: Leiodidae: Cholevinae: Leptodirini). Acta Societatis Zoologicae Bohemicae, 67, 199-202.

Moldovan, O.T., Jalžić, B. \& Erichsen, E., 2004: Adaptation of the mouthparts in some subterranean Cholevidae (Coleoptera, Leiodidae). Natura Croatica, 13(1), 1-18.

Moravec, J. \& Mlejnek, R., 2002: Nauticiella stygivaga gen. n. et sp. n., a new amphibiontic cavernicolous beetle from the Vjetrenica cave, Herzegovina (Coleoptera: Leiodidae: Cholevinae: Leptodirini). Acta Societatis Zoologicae Bohemicae, 66, 293-302.

Nonveiller, G. \& Pavićević, D., 1999: Tartariella durmitorensis n. gen. et n. sp., troisième Leptodirini de la chaîne Dinarique à moeurs hadésiennes (Coleoptera, Leiodidae). Bulletin de la Société Entomologique de France, 104(4), 315-326.

Perreau, M., 2000: Catalogue des Coléoptères Leiodidae Cholevinae et Platypsyllinae. Mémoires de la Société Entomologique de France, 4, 469 pp.

Perreau, M., 2015: Family Leiodidae Fleming, 1821. In: Löbl, I. \& LÖBL, D. (Eds.), Catalogue of Palaearctic Coleoptera. Vol. 2/1. Hydrophiloidea - Staphylinoidea. Revised and Updated Edition. Brill, Leiden-Boston, pp. 180-291.

Perreau, M. \& Pavićević, D., 2008: The genus Hadesia Müller, 1911 and the phylogeny of Anthroherponina (Coleoptera, Leiodidae, Cholevinae, Leptodirini). pp. 215-239, in: Pavićević D., Perreau M. (eds), Advances in the Studies of Fauna of the Balkan Peninsula. Monography no. 22, Institute for Nature Conservation of Serbia, Belgrade.

Polak, S., Delić, T., Kostanjšek R. \& Trontelj, P., 2016: Molecular phylogeny of the cave beetle genus Hadesia (Coleoptera: Leiodidae: Cholevinae: Leptodirini), with a description of a new species from Montenegro. Arthropod Systematics \& Phylogeny, 74(3), 241-254.

Sкет, В., 2004: The cave hygropetric - a little known habitat and its inhabitants. Archives of Hydrobiology, 160(3), 413-425. 